\title{
Contribution of Large Pig for Renal Ischemia-Reperfusion and Transplantation Studies: The Preclinical Model
}

\author{
S. Giraud, ${ }^{1,2,3,4,5}$ F. Favreau, ${ }^{1,2,3,4,5}$ N. Chatauret, ${ }^{1,3,4,5}$ R. Thuillier, ${ }^{1,2,3,4,5}$ S. Maiga, ${ }^{1,5,6}$ \\ and T. Hauet ${ }^{1,2,3,4,5}$
}

${ }^{1}$ INSERM U927, BP 577, 86000 Poitiers Cedex, France

${ }^{2}$ Service de Biochimie, CHU de Poitiers, 86000 Poitiers, France

${ }^{3}$ IBISA, INRA, Domaine Expérimental du Magneraud, 17700 Surgères, France

${ }^{4}$ Réseau FLIRT, Fédération pour l'Étude de l'Ischémie Reperfusion en Transplantation, 86000 Poitiers, France

${ }^{5}$ Faculté de Médecine et de Pharmacie, Université de Poitiers, 86000 Poitiers, France

${ }^{6}$ Service de Radiologie, CHU de Poitiers, 86000 Poitiers, France

Correspondence should be addressed to T. Hauet, t.hauet@chu-poitiers.fr

Received 28 October 2010; Revised 21 December 2010; Accepted 3 January 2011

Academic Editor: Lawrence Schook

Copyright ( $) 2011$ S. Giraud et al. This is an open access article distributed under the Creative Commons Attribution License, which permits unrestricted use, distribution, and reproduction in any medium, provided the original work is properly cited.

\begin{abstract}
Animal experimentation is necessary to characterize human diseases and design adequate therapeutic interventions. In renal transplantation research, the limited number of in vitro models involves a crucial role for in vivo models and particularly for the porcine model. Pig and human kidneys are anatomically similar (characterized by multilobular structure in contrast to rodent and dog kidneys unilobular). The human proximity of porcine physiology and immune systems provides a basic knowledge of graft recovery and inflammatory physiopathology through in vivo studies. In addition, pig large body size allows surgical procedures similar to humans, repeated collections of peripheral blood or renal biopsies making pigs ideal for medical training and for the assessment of preclinical technologies. However, its size is also its main drawback implying expensive housing. Nevertheless, pig models are relevant alternatives to primate models, offering promising perspectives with developments of transgenic modulation and marginal donor models facilitating data extrapolation to human conditions.
\end{abstract}

\section{Introduction}

Experimental models have accelerated our understanding of diseases' pathophysiology and played a major role in the search for adequate therapeutic interventions. Ischemia reperfusion injury (IRI) remains a leading cause of acute kidney injury (AKI) in both native and transplanted kidneys [1]. IRI is a choreographed process leading to delayed graft function (DGF) and reduced long-term organ survival in transplantation. Cold-storage-induced injury is a pivotal contributing factor to early graft dysfunction in organ recipients. The success of organ transplantation is also critically dependent on the quality of the donor organ which, in turn, is determined by a variety of factors, including donor age, donor management prior to organ procurement, hypothermic storage time, and the quality of organ preservation. Organ preservation is a critical link in the chain of donation-transplantation, having a significant effect on posttransplant graft function and graft survival.

Animal experimental models are also crucial in renal IRI research, as there are only a limited number of in vitro models. Although animal experimentation is contentious and subject to legal and ethical restrictions, large animal models are still extensively used and are necessary to develop safe preclinical protocols directly transferable to human. Indeed, preclinical studies using pig or nonhuman primate play an important role in the evaluation of new medical devices and pharmacological therapy efficacy before their use in clinical studies. The first renal transplantation was performed by Emerich Ullmann in 1902 in dog, and the first porcine kidney transplantation was published in 1965 [2]. The similarity in size, physiology, and in organ development and disease progression make the swine an ideal model for human disease research [3]. Nowadays, the 
porcine model is crucial to adapt surgical procedures and to develop models mimicking for instance deceased after cardiac arrest donors or to test novel preservation solutions in transplantation. This paper provides an overview of porcine models commonly used to evaluate organ transplant protocols and analyzes new surgical models of marginal donors, establishing the pig as a gold standard in renal transplantation research.

\section{Renal Transplantation and Ischemia-Reperfusion Injury Models}

Different models can be considered for renal transplantation and IRI. The cellular models are interesting to focus on specific pathways or large-scale screening for drug evaluations. It is possible to use different cell lines originating from different organs. However, the absence of integrative studies, which are only possible at the organ or wholeanimal levels, limits their interest. In fact, in vitro IRI studies cannot mimic the global situation observed in vivo because there are many local, systemic, cellular and humoral factors involved during IRI in vivo. Such models are more adapted to study cold storage conditions with hypoxia and hypothermia mimicking the cold-preservation stage [4-11]. Other models are also useful such as isolated blood vessel models [12]. Indeed, these models are of interest to evaluate signalling pathways and to test hypotheses with preliminary studies [7, 9]. Perfusion of isolated organs are another group of models interesting for an early evaluation of IRI [13-16]. Animal models are an obvious step needed to confirm the most relevant pathways identified at the in vitro in well-controlled systems and to provide a definitive proof of concept [4].

An intermediate step has to be considered with rodent models. There is an extensive literature on renal IRI using rodent models and focusing on the early times of reperfusion with different protocols. A recent paper analysed animal models of chronic allograft injury in kidney, heart, aorta, liver and lung transplantation [17]. This review focused on rodent and nonhuman primate models while the swine model was restricted to lung transplantation. This situation will be changed with the development of mini- or micropigs. In addition, transplantation models in rodents are not easy to perform and are not systematically reproducible mainly because they depend on the operator's skills.

Three large animal models have been used extensively in transplantation: dogs, pigs and nonhuman primates. Each species closely approximates human physiology, and the general anatomical similarity has provided a relevant background for preclinical experiments. In renal transplantation, canine models were used for development of blood vessel anastomosis technique and the first autograft and allograft were performed in dogs. The pig has two major advantages: it is generally accepted for human consumption and the public harbours relatively little resentment for porcine research inducing less legal and ethical restrictions conversely to nonhuman primate or dog models [4]. In addition, pigs are easily bred and are now recognized as being genetically modifiable [18]. Pig has also the advantages of large animal model: it is possible, to collect repeated peripheral blood samples or renal tissue biopsy during experiments, to obtain detailed tissue samples at euthanasia and to use technologies adapted to human conditions such as CTscan or NMR [3]. In terms of genomics, it is an asset that the pig genome has high sequence and chromosome structure homology with humans, making possible the use in pigs of human genetic and proteomic tools [3].

In transplantation research, histology of allograft rejection is similar to humans. Immune responses are predicated on a similar network of $\mathrm{T}$ cells responding to a similarly organized major histocompatibility complex [18]. Although some issues affect the use of immunosuppressors in nonhuman primates and dogs inducing ulcerative bowel lesions and diarrhea due to poor absorption. In these conditions, the pig tolerates high doses of calcineurin inhibitors such as cyclosporine without apparent toxicity.

\section{Description of the Pig As Biomedical Model}

3.1. Anatomy. Many animals have been used in experimental models of renal transplantation but the porcine model is more consistent because of the existence of close analogies between structural features of human and porcine kidneys [19]. Although pig renal and intrarenal anatomy could not be completely transposed to human, many similarities in porcine and human intrarenal arteries have been described [20] as well as anatomical relationships between intrarenal arteries and the kidney collecting system (Figure 1). Using kidney resin perfusions, it was found in 91 pigs that there was only one artery per kidney divided into cranial and caudal branches in $93.4 \%$, or dorsal and ventral branch in $6.6 \%$ of cases [20]. The high occurrence of single renal artery in swine is quite different from the human situation, in which multiple renal arteries are reported in 27 to $30 \%$ of cases [21]. In addition, in the human single artery condition, the primary division occurs into an anterior and a posterior branch [20]. In the renal superior pole, Pereira-Sampaio et al. described two main arteries in pigs (ventral and dorsal) originating from the cranial branch of the renal artery, similar to the human segmental arteries with an apical artery found in human and absents in $67 \%$ of the cases in pigs $[20,22]$. In addition, the dorsal artery, always observed in human, is only described in $47 \%$ of the pig population $[20,22]$ in contrast to the horizontal branch in the ventral mid zone of the kidney, which is always described in both species $[20,22]$. In the inferior pole, the caudal artery divides into ventral and dorsal branches in $85 \%$ of cases in pigs and $62 \%$ in human kidneys. In the remaining cases, the ventral branch arises from the caudal artery and the dorsal branch arises from the dorsal artery [20,22].

As in the human kidney, there are free anastomosis between the intrarenal veins in the pig $[23,24]$. The interlobar veins merge to produce large venous trunks which form the renal vein [24]. Bagetti Filho et al. described two major trunks: cranial and caudal and in few cases, three trunks (cranial, middle and caudal). However, only the ventral surfaces of the cranial and caudal poles were drained by large 


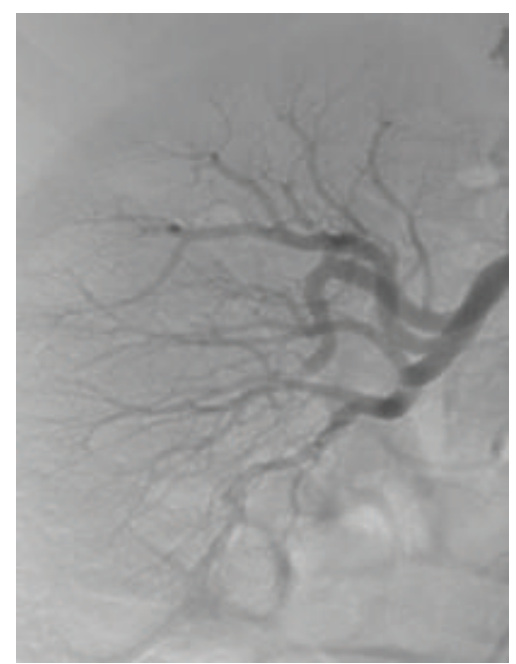

(a)

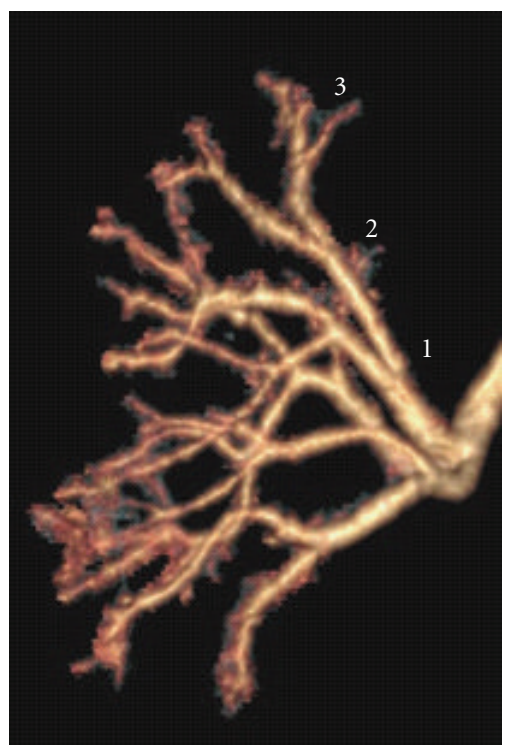

(c)

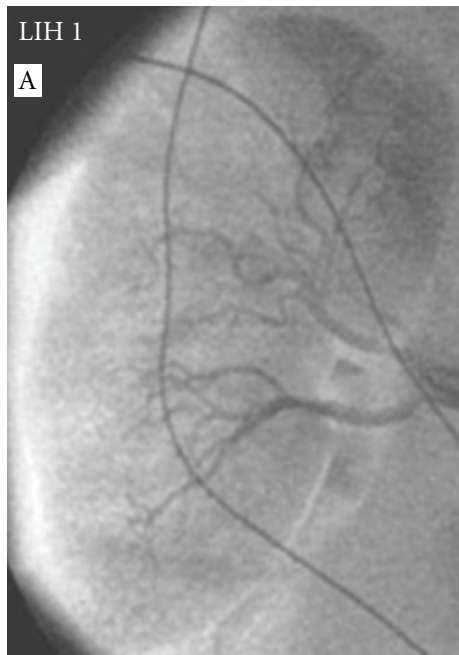

(b)

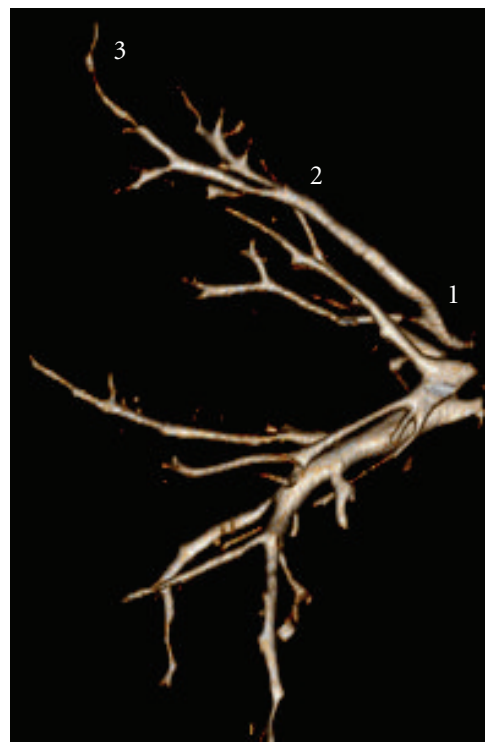

(d)

Figure 1: Renal human and pig vasculature. $(a, b)$ are representative angiography pictures, respectively, in human and pig, (c, d) are representative pictures of kidney vasculature obtained with CTscan, respectively, in human and pig. (1) segmental arteries aera; (2) interlobar arteries aera; (3) arcuate arteries aera.

veins while the dorsal surfaces emptied by anastomoses into the ventral interlobar veins [24]. The arterial and venous architectures in each species vary significantly and have evolved to optimise $\mathrm{O}_{2}$ transport based on each unique anatomical configuration. In dogs and rodents, segmental arteries are bypassed due to the lack of multiple medullary pyramids, while in humans and pigs an elaborate system of interlobar and segmental arteries is present to supply the numerous kidney lobes [25]. There is thus a high degree of proximity between human and pig kidneys [20] (Figure 2), with multilobular, multipapillary architecture, while mice, rats, dogs and rabbits have unilobular, unipapillary kidneys [25].

In term of body size, pig is also close to human, particularly for the mini-pig which reaches body weights of
$60-70 \mathrm{~kg}$ in adulthood. The large blood volume in pigs allows repeated blood sampling. The use of males greatly facilitates $24 \mathrm{~h}$-urine collection in metabolic cages which is a crucial parameter to monitor in renal transplantation.

3.2. Physiology. The mechanisms of IRI, depend on the anatomic and metabolic properties of the kidney [27]. In association with the multilobular, multipapillary kidney and the vascular architecture, renal parenchyma oxygenation is graded with the highest $\mathrm{O}_{2}$ levels in the cortical zone, medium levels in the outer medulla and the lowest levels in the papillae [25]. Cells in each kidney region are adapted to function optimally at the oxygenation levels in their respective microenvironments [27]. Cortical cells mainly use 


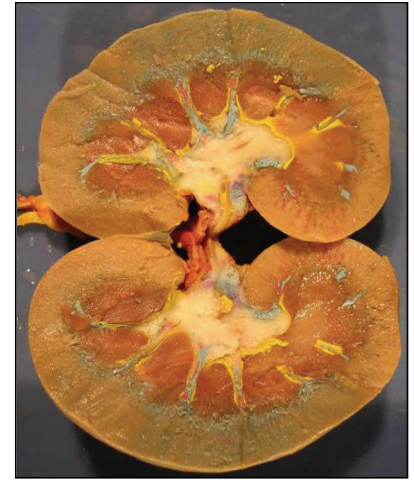

Human

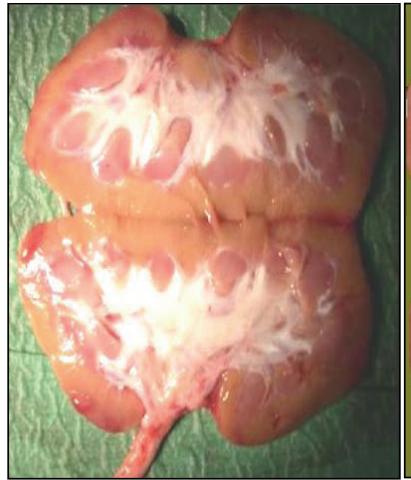

Pig

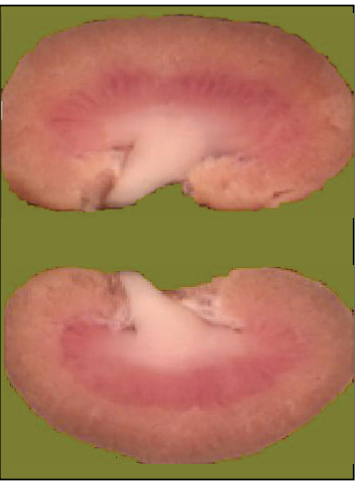

Rodent

FIGURE 2: Renal anatomical comparisons between human, pig and rodent [26]. Multilobular and multipapillary kidneys observed in human and pig contrast with unilobular and unipapillary kidney in rodent (http://www.jeremyswan.com/).

$\mathrm{O}_{2}$-dependent metabolism linked to oxidative phosphorylation. These cells are living in an oxygenated area making them more sensitive to ischemia. Cells in the outer medulla can shift to $\mathrm{O}_{2}$ independent metabolism, making them less sensitive to an hypoxic environment. Inner medulla and papillae cells predominantly use glucose to generate ATP via anaerobic glycolysis. These last regions reside in a permanent hypoxic environment and consequently are less affected by ischemia [25]. Physiological differences among species limit the clinical translation of animal studies. Criteria related to renal embryology, anatomy, architecture and lymphatic pattern, ability to concentrate urine, and sensitivity to ischemia suggest that the pig kidney may be more similar to the human kidney than dog's or rodent's and may be a better model to study human ischemia/reperfusion consequences $[25,28-30]$.

3.3. Biochemistry. Human reference values for blood biochemical parameters, such as creatinine and Blood Urea Nitrogen (BUN) are identical in pigs [31]. A previous study analysed over 100 physiological variables in pigs in basal conditions, concluded that most porcine values were similar to those collected under comparable conditions in humans [31].

3.4. Genome. Major advances in the understanding of the porcine transcriptome have occurred over the past decade, and especially in the past few years [32]. The pig genome was sequenced and characterised under the auspices of the Swine Genome Sequencing Consortium [33, 34]. Microarray and macroarray from Sus Scrofa cDNA have been used since 2005 [35] and chips for immune system are now well established [36-41]. This new technology has been used to characterize a preclinical model of chronic ischemic wound [42] and to study hypoxia effects on stem cells [43]. The important crossspecies of gene expression between human and porcine tissue supports the concept of using human GeneChip microarray platform to compare gene expression profiles between pig and human tissues in the absence of a porcine microarray platform [44].
3.5. Immune System. The porcine immune system is better characterized than the canine one, making the pig an interesting alternative model to the nonhuman primate for immunosuppressive therapeutic approaches. The porcine immune system has been studied to elucidate the role of the lymphoid organs during infectious diseases, in order to characterize immune function in transplantation research and to generate a model for various aspects of human immunology [45]. Immunosuppressive drugs have been evaluated in dogs, pigs and nonhuman primates leading to reproducible prolongations of graft survival [4]. The pig is also important to investigate the development of the adaptative immune response in neonates [46, 47]. Studies on laboratory rodents or primates have been ambiguous because neither the effect of environmental nor maternal factors on the newborn can be controlled in mammals such as transmission of potential maternal immunoregulatory factors in utero.

Workshop and literature on immune marker identifications report important similarities between human and pig antigens as well as immune response [6, 48-51]. Through these workshops, the available antibodies used in pig studies have increased drastically $[6,50,52-58]$.

3.6. Immunosuppressive Therapies in Large Animal Models. A recent review has presented the different aspects and showed that large animal model could be useful for therapeutic protein fused to monoclonal antibodies, depletion strategies, mixed chimerism or donor antigen infusion [4].

\section{Limits of the Large Pig Model}

Although the porcine model is herein described as a gold standard, it presents several disadvantages. The major inconvenient resides in its fast growth and subsequent large size, complicating handling. In terms of reproduction, a female pig has a gestation period of 114 days, with an average of 2.4 litters per year and 12 piglets per litter, requiring a large kennel. Pigs are often considered noisy and aggressive causing researchers to consider more amenable species to 
perform their experiments [59]. In fact, male pigs usually require castration to limit their aggressive behavior at the end of puberty.

Pigs need to be used at a reasonable weight in order to easily perform transplantation surgeries in laboratories under sterile conditions. Therefore the age of the animals used for transplantation is restricted to very young adults rather than adults [4]. Their relatively rapid growth impairs the setting up of long-term studies [60]. In fact, the Large White pigs commonly used in our laboratory, weigh around $1.5 \mathrm{~kg}$ at birth, $35 \mathrm{~kg}$ at 3 months, $125 \mathrm{~kg}$ at 6 months, $200 \mathrm{~kg}$ at 1 year and $280 \mathrm{~kg}$ at 2 years. At 3 months, the pig needs a large amount (estimated at $1 \mathrm{~kg}$ per day) of relatively expensive food: commonly diet prices range from 0.2 euros $/ \mathrm{kg}$ for standard diet to 3.5 euros $/ \mathrm{kg}$ for hyperlipidemic diet. Studies in pigs are expensive and consequently include a smaller number of animals. A Large White pig costs around 120 euros at $30 \mathrm{~kg}$ and requires important handling, surgical material, such as a pen, a metabolic cage for urine collection (around 2500 euros/unit), a surgical room similar to the ones used for humans, and a large area to stock food. Their large size and the necessity to induce general anesthesia require larger amounts of anesthetics and more human manipulators than for small animal models. A second major limiting point is the adaptation of the material required for biological analysis. In fact, porcine specific antibodies and kits for biological marker detection are rare and expensive; however new tools are emerging due to the expansion of the use of pig as a common experimental model. In addition, human protein analysis kits can be used with porcine samples due to the biological proximity between pig and human. Another point is the limited number of references available in the literature for pig biological data. In summary, the most significant disadvantages of the Large White pig include difficulties in handling, maintenance and high costs.

\section{Minipig Model: An Alternative of Large Pig Model}

5.1. Rational for Minipig Models. In porcine experimentation, the animal's size is crucial. Indeed, smaller animals are easier to breed and handle than larger ones. The large weight of fully grown farm pigs (up to $250 \mathrm{~kg}$ ) impairs their routine laboratory use [4]. Thus, several types of miniature pigs also termed "minipigs", have been developed. The predominant breeds are the Yucatan, Hanford, Göttingen and Sinclair. These breeds and dozens of others have been used as experimental models for various clinical situations [61]: (i) the Hanford minipig breed has been used for urological studies $[62,63]$, (ii) the Yucatan breed, the only natural occurring miniature pig, is one of the predominant models used for cardiovascular physiology and congestive heart failure studies [64, 65], and (iii) the Gottingen minipig is used for comparative drug distribution and pharmacokinetic studies [66-68].

For instance, the Hanford minipig is sociable, trainable, and weighs only 25 to $35 \mathrm{~kg}$ at 4 to 6 months old [62]. The average kidney size in a $25 \mathrm{~kg}$ Hanford minipig is $120 \mathrm{~g}$ and measures $11 \times 6 \times 3 \mathrm{~cm}$, similar to the kidney of a $70 \mathrm{~kg}$ human [62]. The sexual maturity of minipig is reached at around 4-5 months old corresponding to a body weight of 15-20 kg for Sinclair pigs, 20-25 kg for Yucatan pigs and 20$30 \mathrm{~kg}$ for the Hanford breed.

The major advantage of using minipigs is their relative low maintenance costs in comparison to large pigs [69]. Indeed, minipigs require less housing surfaces, food (divided by two or more) and less drug amounts. The latter point is particularly appreciated when the drug is under evaluation and only produced on a small expensive scale.

5.2. Minipig Inconveniences. Minipig's smaller body size could be a disadvantage to perform experiments in clinical conditions. Indeed, human surgical protocols or instruments can sometimes not be used in minipigs. Small size makes this type of pigs unsuitable for the modelling of the normothermic extracorporeal circulation used for transplantation of kidneys obtained from deceased after cardiac arrest donors [70, 71], mainly because of a smaller vascular size in minipigs in comparison to human, [72-75]. Taken together, the basic knowledge of Large White models acquired during the last twenty years for kidney transplantation studies, contrasts with minipig studies mainly limited to noninvasive surgical experiments. Despite these inconvenients, the use of minipigs as a kidney transplantation model may be one of the few available animal model for the study of extended criteria donors such as older or diabetic donors.

\section{Different Models for Renal Transplantation and Ischemia-Reperfusion Injury}

6.1. Anaesthesia and Surgical Aspects. Most experiments in the transplantation area are carried out on rodents, but crucial prerequisites for the development of safe preclinical protocols in biomedical research are needed through the use of suitable large animal models needing anaesthesia and surgery similar to human.

6.1.1. Anesthesia Procedure. Pig is a valuable animal for anesthesia experimental studies. This procedure needs to ensure optimal perioperative analgesic control with motor blockade during surgery associated with a rapid postoperative recovery. In our laboratory, we have developed epidural anesthesia techniques in pigs [76] which allow us to conduct pharmacological and pathophysiological studies $[77,78]$.

6.1.2. Surgical Procedures. Surgical procedures, postoperative course, peri- and postoperative monitoring are necessary in large animal models to provide an optimal tool for surgeon training and resident teaching. Indeed, pigs could be used as preclinical models mimicking true clinical situations which are sometimes complex $[79,80]$. Pig models have also been used to develop new surgical aspects [81-84] with a possible rapid translation to the clinical situation mainly because of the pig's body size. 


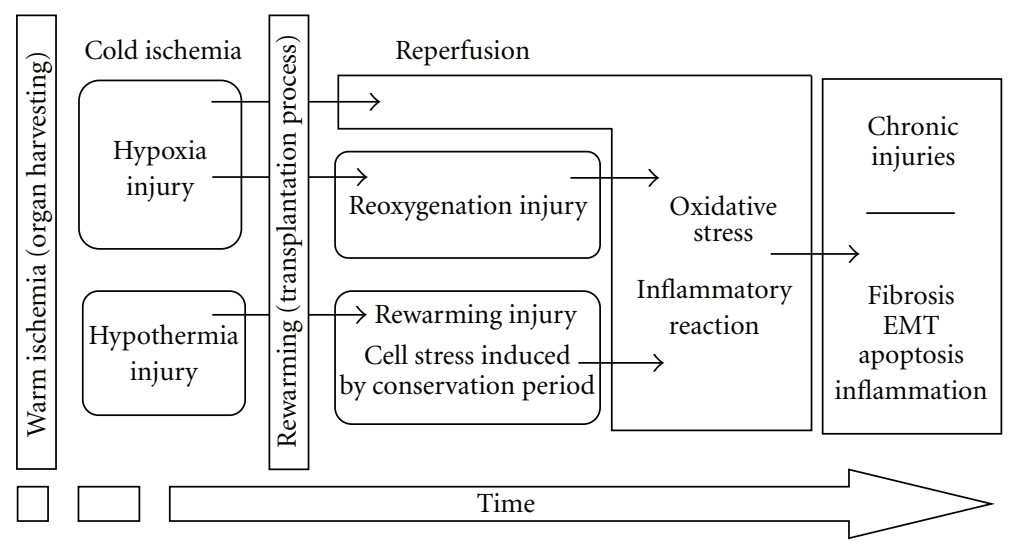

FIGURE 3: Major processes induced by ischemia-reperfusion injury in renal transplantation.

6.2. Ischemia-Reperfusion Sequences. IRI is known as one of the central nonimmunologic process involved in renal allograft dysfunction implicating vascular and tubular injuries [85]. More than ever, research into the mechanisms of warm ischemia (WI), cold storage (CS), and IRI is needed to maximize the use of the available donor pool and to minimize primary nonfunction (PNF) and delayed graft function (DGF). Although advances in organ preservation solutions and techniques allowed prolongation of hypothermic storage [86], the effects of CS after a period of WI are still incompletely understood. The use of preclinical model in a large animal such as the pig is necessary to adapt transplantation processes closely related to the human condition and clarify the mechanisms involved. Well-known in rodent, renal WI has been scarcely investigated in clinical situations such as transplantation.

Several porcine models have been used to study the mechanisms of WI and the effects of a variety of drugs, and some of them are moving on to clinical evaluation [87-89]. Because the porcine renal anatomy and vascular bed are very similar with human kidneys, these models are very relevant to evaluate the renal response following injury, such as renal tubular inflammation and repair processes [90]. The choice of animal model is crucial to validate proper markers. We and others have validated several precious markers in pigs for pivotal pathways that mediate injury responses and recovery after renal ischemia [75, 88, 89, 91-93].

6.3. Kidney Transplantation. Kidney transplantation and particularly preservation time characterized WI and CS combination leading to IRI (Figure 3 ). In this setting, translation of experimental findings into effective interventions in human situation requires preclinical studies using an adapted model of large animal. The pig is highly useful to reach this goal because of important similarity between human and pig kidney [19].

6.3.1. Renal Failure and Transplantation. Kidney transplantation is the treatment of choice for end-stage renal failure.

The growing demand of kidney graft for transplantation leads transplantation centres to consider others sources of donor organs. The use of expanded criteria donors, deceased after cardiac arrest donors or donors with acute renal failure has been proposed to limit the organ shortage, especially for kidney [94]. Kidneys from donors with acute renal failure are exposed to additional time of WI followed by the conventional CS period. The grafts from such donors exhibit higher rates of DGF and PNF which are the main barriers to use safely these grafts [95]. The ideal transplant model should replicate these clinical conditions mimicking human surgery, graft rejection, response to immunosuppressors, and functional recovery.

6.3.2. Autotransplantation. Fifteen years ago, we have developed an auto-transplant model using Large White male pigs weighing $30-35 \mathrm{~kg}$, which were prepared as described previously in accordance with the French guidelines of the Ethical Committee for Human and Animal Studies [91, $96,97]$. Briefly, the right kidney is harvested, cold flushed with approximately $400 \mathrm{~mL}$ of preservation solution, and preserved for $24 \mathrm{~h}$ at $4^{\circ} \mathrm{C}$ immersed in the solution. The left kidney is removed during the transplantation surgery to mimic the nephron mass in the clinical transplanted situation.

We have validated several markers in the pig model of renal autotransplantation using histological tools, ${ }^{1} \mathrm{H}-\mathrm{NMR}$ spectroscopy and different biochemical analyses [98-100]. This model is interesting for relevant evaluations of IRI, inflammation and preservation solution effect [100]. From this preclinical model, we developed a new preservation solution now routinely used in clinic [101]. In addition, different drugs were tested with interesting results and clinical studies will be launched [91, 101-105]. This model was used also to assess the interstitial fibrosis and tubular atrophy development after 3- to 4-month followups and protocol biopsies offer new possibilities to predict kidney graft outcome [106]. For ten years, we have developed this approach to study fibrosis development (using red Sirius staining) and inflammatory cells infiltration [97, 107]. We have outlined, in this autotransplantation model, the role of CD4 positive cells, monocytes/macrophages and the proper effect of cold preservation. Such animal model is 
interesting because renal biopsy data bring information on the pathophysiology development. This clinically relevant model of autotransplantation offers the possibility to study various aspects related to kidney preservation without the interference of an allogenic immune response. Several authors have used such model in renal transplantation. Other groups have reported the utility of these models and confirm their interests in preclinical testing of novel surgical procedures that mitigate harmful effect of renal ischemia $[74,93,108-113]$.

6.3.3. Allotransplantation. In this model, we have adapted the auto-transplantation condition to allograft matching. Analysis of preoperative blood samples ensure compatibility for swine leucocyte antigen (SLA) class I. The microsatellite technique was used to ensure less than 10 per cent recombination for the class II SLA, permitting graft survival with low-grade acute rejection without immunosuppression [114-116]. For this model, recipients' right kidneys were removed and the donor graft was implanted by end-to-side anastomosis on the aorta and inferior vena cava. The left kidney was removed to mimic the nephron mass in the transplanted situation. Using this model, we have determined the effect of polyethylene glycol polymers on graft recovery [117]. In addition, we have completed inflammatory studies with an evaluation of cell infiltration and tubulo-interstitial fibrosis.

6.3.4. Impact of Immature versus Mature Animals on Kidney Function. Nephrology studies, using human markers of renal function such as 24 -h diuresis, creatinemia, or proteinuria, are performed either in young large pigs weighing between 20 to $35 \mathrm{~kg}$ [118-122] or in more mature animals: $>35 \mathrm{~kg}$ [72, $73,97,123,124]$.

As mentioned before, the large size of pigs implies that young adults are mostly used for kidney transplantation experiments. The use of young animal could impact the results obtained and their extrapolation to the human situation. Indeed, immature kidney could have better regenerative capacities in response to injury. This hypothesis underlines a potential low rate of PNF and DGF in young pigs in contrast to mature animals and supports the young pig model to investigate the renal reparation processes. In term of immunity function, young animals are usually protected from immune challenge [4]. For these reasons the data obtained in young animals have to be confirmed in mature pigs [4]. For instance, in our laboratory, porcine kidney graft is performed in 3-month-old pigs and the followup is around 3 to 6 months. On the other hand, for long-term studies, mature animals allow to investigate the real impact of injury in adult kidneys [4].

The limit of large pig model is mainly due to the large animal size compensated by the use of young animals with immature kidneys. Minipig will be the model of choice to evaluate the influence of kidney maturity.

6.3.5. Renal Chronic Damage and Ischemia-Reperfusion Injury. The majority of research in this field has been performed in small animal models, but extrapolation of data obtained in rodents to humans is difficult [28]. Large animal models are useful for long-term studies of IRI particularly in the context of transplantation. Preferably, the response of the kidney to IRI needs to be also studied in a model closer to humans. The pig is the ideal species to serve this purpose [28]. In different renal ischemic conditions, in pig we have analyzed the role of IRI in tubule interstitial fibrosis development at three months post-transplantation $[87,88$, $92,96,101,102,105,125-130]$.

6.4. Marginal Donor Models and Donation after Cardiac Death Models. The demand for kidney transplantation has increased dramatically in the past few years. The critical shortage of organs has led to alternative strategies to expand the donor pool. The use of kidneys from expanded criteria or marginal donors (ECDs) represents an option to reduce the disparity between organ supply and demand. All donors aged over 60 , and donors aged 50-59 with at least two of three additional risk factors were considered marginal. The three additional risk factors identified were cerebrovascular accident as a cause of death, history of hypertension, and serum creatinine above $1.5 \mathrm{mg} / \mathrm{dL}$ prior to transplantation. This definition of ECD has now been validated by a consensus meeting organized by the American Society of Transplantation in Crystal City which has developed guidelines for the management of marginal kidneys [131]. In addition, to improve the stratification and the identification of deceased donor kidneys with an increased risk of early graft dysfunction and graft loss, Nyberg et al. designed another scoring system, the Deceased Donor Score (DDS) [132]. There are seven donor variables significantly influencing the creatinine clearance of recipients at 6 months: age, creatinine clearance, history of hypertension, Human Leucocyte Antigen (HLA) mismatch, cause of death, ethnicity and cold ischemia time (for review see [133]).

Organ donation after cessation of cardiac pump activity is referred to as nonheart-beating organ donation (NHBOD) or donation after cardiac death (DCD). This condition is one of the strategies that have been implemented in order to face organ shortage. DCD is internationally considered to be an encouraging source of organs for transplantation. However, physicians are reluctant to use such organs because they have a high risk of DGF and PNF.

There is room for experimental studies in these fields and particularly for large animal models. Several recent studies have shown that promising protocols could be used in the clinical situation $[92,102,103,120,126]$. More recently, new protocols have been evaluated and the use of normothermic venoarterial extracorporeal membrane oxygenation support seems an interesting alternative [80]. Further experimental studies are warranted to clarify the effect of such protocols.

\section{Metabolic Diseases Models}

It could be of great interest to develop marginal donor models with experimental situation mimicking human pathologies. Several experimental models have enhanced 
understanding of atherothrombosis pathophysiology and have played a major role in the search for adequate therapeutic interventions $[134,135]$. Various animal models have been developed to simulate thrombosis and to study in vivo parameters related to hemodynamics and rheology changes that lead to thrombogenesis [136-140]. Other models could be also associated with metabolic situations such as reduced nephronic mass model [141]. Disease progression in pigs share similarities with the human aspect such as obesity, diabetes, dyslipidemia or atherosclerosis and hypertension [142-148]. The swine can be used in studies of renal hypertension such as a model of deoxycorticosterone saltinduced hypertension or renin-induced hypertension [149].

\section{Other Models}

Large animal models have been also used to study the effects of brain death $[150,151]$. Such models are of interest to characterize and clarify a major stage before organ collection associated with the inflammatory and cytokines "storm" which has deleterious effects on organ quality.

\section{Future Approachs}

The swine have served as an important model for human biology [3]. This model requires a greater international interest and new tools are rapidly developing.

9.1. Genetically Modified Pig. Genetically modified pigs are now available in experimentation. Production of transgenic pigs for xenotransplantation started 15 years ago [152]. The first reported transgenic modifications of swine involved introduction of human complement-regulatory proteins (CRPs) as transgenes into outbred swine. The most human CRPs transgenic pig models have been hDAF [153], hCD46 [154] and hCD59 [155].

In addition, another pig model was isolated at the end of the nineties. This model presents a spontaneous mutation of the low density lipoprotein receptor gene associated with recessive familial hypercholesterolemia in swine (FHD pig) [156]. Because anti-Gal antibodies were considered to be the major cause of humoral rejection in pig-to-primate kidney Xenotransplantation, an alpha1,3 galactosyltransferase knockout (GalT-KO) pig was developed [157, 158].

9.2. Xenotransplantation. Xenotransplantation represents an immense potential to solve the critical graft shortage and could be a new source of organs, tissues and cells for clinical transplantation [152, 158-162]. Pigs are considered the ideal donor for kidney transplantation to human recipients [44]. In order to generate the necessary data to allow xenotransplantation to progress towards its initial clinical phase, the European Union has created XENOME, a European Commission-funded multidisciplinary effort. Xenome is an integrated project in the European Sixth Framework Programme (Life Sciences, Genomics and Biotechnology for Health).
9.3. Stem Cells. Embryonic stem cells (ESCs) represent a promising tool for cell therapy, regenerative medicine and tissue repair. Assessment of ESC capacities in species other than the mouse is an ongoing topic of interest and is crucial to allow a rapid transfer to clinical applications. A recent review place the pig among the best models for preclinical development [163]. Pig is a particularly desirable species to create pluripotent cell lines because of its value as a biomedical model in transplantation at a time when the safety of ESC use needs to be evaluated in large animal models before human application [164-166].

\section{Conclusion}

Although the major part of studies in the field of ischemiareperfusion has been performed in rodent models, but the pig is becoming the model of choice for preclinical studies [28]. The rodent model is cheaper and easier to manage in the laboratory, however, the studies are limited because of a difficult data extrapolation to human mainly due to kidney anatomical differences between these two species. The large swine model is a valuable model for renal transplantation, with anesthesia and surgical processes very similar to the human conditions offering a good training model for surgery students. In addition, surgery team can evaluate new potential of kidney donor models like DCD and assess new preservation techniques adapted to human like kidney machine perfusion. Pig is one of the rare species which is characterized by a human-like renal anatomic structure with multipapillary and multilobular kidneys. However, the pig size is the main limit of this model, requiring adapted area, expensive food, drugs and surgical materials. Minipigs could be used in parallel for long-term studies with an adult weight around $60 \mathrm{~kg}$. The advantages of rodent models like gene knockout or genetic manipulations is now applicable in pigs offering new perspectives for preclinical studies. Embryonic stem cells therapy already investigated in rodents will soon be tested in pigs to show its clinical interest for kidney graft injuries therapy.

\section{Acknowledgments}

The authors are grateful to Drs M. Eugene, D. Bon, L. Lacoste, J. Cau, J. P. Richer, C. Jayle, T. Desurmont, G. Febrer, O. Page, G. Regnault de la Motte, H. Baumert, J. P. Faure, G. Mauco, J. M. Goujon, M. Scepi, J. Roumy, H. Lathelize, O. Page, A. Gagnat, A. Valagier, A. Mameli, O. Celhay, M. Tri Ngo, A. Puichaud, G. Allain, V. Bourgade, P. O. Delpech, G. Goudard, T. Saint-Yves, B. Roussel, J. Danion, F. Seguin, M. Carretier, S. Deretz, C. Nadeau, B. Doré, H. Gibellin, R. Codas, R. Thuret, C. Billault, N. Vaziri, A. Bellereaud, C. Doucet, N. Maillot, A. Ouattara, J. M. Pechier, J. Rouffineau, J. C. Caritez, D. Bon, D. Mothes, W. Hebrard, C. Henry, E. Manoury, P. Couturier, Y. Billon, S. Joffrion, D. Lochon, P. Decourt, M. Jacquard, V. Ameteau, F. Ribardière, N. Boildieu, B. Fernandez, N. Quellard, S. Tillet, L. Rossard, V. Mallet, for their excellent assistance in the conduction of different studies, which contributed to 
this review. The authors wish to acknowledge the generous support from Conseil Général de la Vienne, Région Poitou Charentes, Banque Tarneaud Poitiers, CHU de Poitiers, Inserm, Fondation CENTAURE, réseau FLIRT, and Société Francophone de Transplantation.

\section{References}

[1] H. R. Jang, G. J. Ko, B. A. Wasowska, and H. Rabb, "The interaction between ischemia-reperfusion and immune responses in the kidney," Journal of Molecular Medicine, vol. 87, no. 9, pp. 859-864, 2009.

[2] A. M. Mery, M. Sekiguchi, W. E. Vaubel, J. Poisson, and J. P. Lamelin, "Kidney transplantation in the pig: surgical approachGreffe de rein chez le porc: approche chirurgicale," Comptes Rendus Hebdomadaires des Seances de l'Academie des Sciences, vol. 260, no. 21, pp. 5631-5633, 1965.

[3] J. K. Lunney, "Advances in swine biomedical model genomics," International Journal of Biological Sciences, vol. 3, no. 3, pp. 179-184, 2007.

[4] J. P. Dehoux and P. Gianello, "The importance of large animal models in transplantation," Frontiers in Bioscience, vol. 12, pp. 4864-4880, 2007.

[5] A. K. Salahudeen, M. Nawaz, V. Poovala et al., "Cold storage induces time-dependent F-isoprostane formation in renal tubular cells and rat kidneys," Kidney International, vol. 55, no. 5, pp. 1759-1762, 1999.

[6] K. Haverson, A. Saalmüller, Z. Chen et al., "Summary of the first round analyses of the Third International Workshop on Swine Leukocyte Differentiation Antigens," Veterinary Immunology and Immunopathology, vol. 80, no. 1-2, pp. 2534, 2001.

[7] D. Dutheil, I. Rioja-Pastor, C. Tallineau et al., "Protective effect of PEG 35,000 Da on renal cells: paradoxical activation of JNK signaling pathway during cold storage," American Journal of Transplantation, vol. 6, no. 7, pp. 1529-1540, 2006.

[8] U. Rauen, U. Kerkweg, M. C. Wusteman, and H. de Groot, "Cold-induced injury to porcine corneal endothelial cells and its mediation by chelatable iron: implications for corneal preservation," Cornea, vol. 25, no. 1, pp. 68-77, 2006.

[9] U. Rauen and H. de Groot, "New insights into the cellular and molecular mechanisms of cold storage injury," Journal of Investigative Medicine, vol. 52, no. 5, pp. 299-309, 2004.

[10] U. Rauen, U. Kerkweg, D. Weisheit, F. Petrat, R. Sustmann, and H. de Groot, "Cold-induced apoptosis of hepatocytes: mitochondrial permeability transition triggered by nonmitochondrial chelatable iron," Free Radical Biology and Medicine, vol. 35, no. 12, pp. 1664-1678, 2003.

[11] U. Kerkweg, M. Jacob, H. de Groot, H. G. Mannherz, and U. Rauen, "Cold-induced apoptosis of rat liver endothelial cells: contribution of mitochondrial alterations," Transplantation, vol. 76, no. 3, pp. 501-508, 2003.

[12] T. Wille, H. de Groot, and U. Rauen, "Improvement of the cold storage of blood vessels with a vascular preservation solution. Study in porcine aortic segments," Journal of Vascular Surgery, vol. 47, no. 2, pp. 422-431, 2008.

[13] C. Jayle, T. Hauet, E. Menet et al., "Beneficial effects of polyethylene glycol combined with low-potassium solution against lung ischemia/reperfusion injury in an isolated, perfused, functional pig lung," Transplantation Proceedings, vol. 34, no. 3, pp. 834-835, 2002.
[14] T. Hauet, J. M. Goujon, C. Tallineau, M. Carretier, and M. Eugene, "Early evaluation of renal reperfusion injury after prolonged cold storage using proton nuclear magnetic resonance spectroscopy," British Journal of Surgery, vol. 86, no. 11, pp. 1401-1409, 1999.

[15] S. J. F. Harper, S. A. Hosgood, H. L. Waller et al., "The effect of warm ischemic time on renal function and injury in the isolated hemoperfused kidney," Transplantation, vol. 86, no. 3, pp. 445-451, 2008.

[16] S. A. Hosgood, A. Bagul, M. Kaushik, J. Rimoldi, R. S. Gadepalli, and M. L. Nicholson, "Application of nitric oxide and carbon monoxide in a model of renal preservation," British Journal of Surgery, vol. 95, no. 8, pp. 1060-1067, 2008.

[17] D. S. Bedi, L. V. Riella, S. G. Tullius, and A. Chandraker, "Animal models of chronic allograft injury: contributions and limitations to understanding the mechanism of longterm graft dysfunction," Transplantation, vol. 90, no. 9, pp. 935-944, 2010.

[18] A. D. Kirk, "Crossing the bridge: large animal models in translational transplantation research," Immunological Reviews, vol. 196, pp. 176-196, 2003.

[19] D. H. Sachs, "The pig as a potential xenograft donor," Veterinary Immunology and Immunopathology, vol. 43, no. 13, pp. 185-191, 1994.

[20] M. A. Pereira-Sampaio, L. A. Favorito, and F. J. B. Sampaio, "Pig kidney: anatomical relationships between the intrarenal arteries and the kidney collecting system. Applied study for urological research and surgical training," Journal of Urology, vol. 172, no. 5, part 1, pp. 2077-2081, 2004.

[21] K. S. Satyapal, A. A. Haffejee, B. Singh, L. Ramsaroop, J. V. Robbs, and J. M. Kalideen, "Additional renal arteries: incidence and morphometry," Surgical and Radiologic Anatomy, vol. 23, no. 1, pp. 33-38, 2001.

[22] F. J. B. Sampaio and A. H. M. Aragao, "Anatomical relationship between the intrarenal arteries and the kidney collecting system," Journal of Urology, vol. 143, no. 4, pp. 679-681, 1990.

[23] F. J. Sampaio, "Anatomical background for nephron-sparing surgery in renal cell carcinoma," Journal of Urology, vol. 147, no. 4, pp. 999-1005, 1992.

[24] H. J. S. Bagetti Filho, M. A. Pereira-Sampaio, L. A. Favorito, and F. J. B. Sampaio, "Pig kidney: anatomical relationships between the renal venous arrangement and the kidney collecting system," Journal of Urology, vol. 179, no. 4, pp. 1627-1630, 2008.

[25] M. N. Simmons, M. J. Schreiber, and I. S. Gill, "Surgical renal ischemia: a contemporary overview," Journal of Urology, vol. 180, no. 1, pp. 19-30, 2008.

[26] V. A. Jacob, C. M. Harbaugh, J. R. Dietz et al., "Magnetic resonance imaging of urea transporter knockout mice shows renal pelvic abnormalities," Kidney International, vol. 74, no. 9, pp. 1202-1208, 2008.

[27] P. Silva, "Energy and fuel substrate metabolism in the kidney," Seminars in Nephrology, vol. 10, no. 5, pp. 432-444, 1990.

[28] W. Lieberthal and S. K. Nigam, "Acute renal failure. II. Experimental models of acute renal failure: imperfect but indispensable," American Journal of Physiology, vol. 278, no. 1, pp. F1-F12, 2000.

[29] D. Killion, C. Canfield, J. Norman, and J. T. Rosenthal, "Exogenous epidermal growth factor fails to accelerate functional recovery in the autotransplanted ischemic pig kidney," Journal of Urology, vol. 150, no. 5, part 1, pp. 15511556, 1993. 
[30] B. Schmidt-Nielsen and R. O'Dell, "Structure and concentrating mechanism in the mammalian kidney," The American journal of physiology, vol. 200, pp. 1119-1124, 1961.

[31] J. P. Hannon, C. A. Bossone, and C. E. Wade, "Normal physiological values for conscious pigs used in biomedical research," Laboratory Animal Science, vol. 40, no. 3, pp. 293298, 1990.

[32] C. K. Tuggle, Y. Wang, and O. Couture, "Advances in swine transcriptomics," International Journal of Biological Sciences, vol. 3, no. 3, pp. 132-152, 2007.

[33] A. L. Archibald, L. Bolund, C. Churcher et al., "Pig genome sequence-analysis and publication strategy," BMC Genomics, vol. 11, no. 1, article 348, 2010.

[34] L. B. Schook, J. E. Beever, J. Rogers et al., "Swine Genome Sequencing Consortium (SGSC): a strategic roadmap for sequencing the pig genome," Comparative and Functional Genomics, vol. 6, no. 4, pp. 251-255, 2005.

[35] S. H. Zhao, J. Recknor, J. K. Lunney et al., "Validation of a first-generation long-oligonucleotide microarray for transcriptional profiling in the pig," Genomics, vol. 86, no. 5, pp. 618-625, 2005.

[36] YU. Gao, L. Flori, J. Lecardonnel et al., "Transcriptome analysis of porcine PBMCs after in vitro stimulation by LPS or PMA/ionomycin using an expression array targeting the pig immune response," BMC Genomics, vol. 11, no. 1, article 292, 2010.

[37] D. P. Gladue, J. Zhu, L. G. Holinka et al., "Patterns of gene expression in swine macrophages infected with classical swine fever virus detected by microarray," Virus Research, vol. 151, no. 1, pp. 10-18, 2010.

[38] L. T. Fernandes, A. Tomás, A. Bensaid et al., "Exploratory study on the transcriptional profile of pigs subclinically infected with porcine circovirus type 2," Animal biotechnology, vol. 20, no. 3, pp. 96-109, 2009.

[39] M. K. Kim, J. Y. Oh, J. H. Ko et al., "DNA microarray-based gene expression profiling in porcine keratocytes and corneal endothelial cells and comparative analysis associated with Xeno-related rejection," Journal of Korean Medical Science, vol. 24, no. 2, pp. 189-196, 2009.

[40] Z. Shi, J. Sun, H. Guo, and C. Tu, "Genomic expression profiling of peripheral blood leukocytes of pigs infected with highly virulent classical swine fever virus strain Shimen," Journal of General Virology, vol. 90, no. 7, pp. 1670-1680, 2009.

[41] M. I. Nino-Soto, R. J. Jozani, B. Bridle, and B. A. Mallard, "Analysis of gene expression patterns by microarray hybridization in blood mononuclear cells of SLA-DRB1 defined Canadian Yorkshire pigs," BMC Research Notes, vol. 1, article 31, 2008.

[42] S. Roy, S. Biswas, S. Khanna et al., "Characterization of a preclinical model of chronic ischemic wound," Physiological Genomics, vol. 37, no. 3, pp. 211-224, 2009.

[43] S. Wang, Y. Zhou, C. N. Seavey et al., "Rapid and dynamic alterations of gene expression profiles of adult porcine bone marrow-derived stem cell in response to hypoxia," Stem Cell Research, vol. 4, no. 2, pp. 117-128, 2010.

[44] G. Shah, M. Azizian, D. Bruch, R. Mehta, and D. Kittur, "Cross-species comparison of gene expression between human and porcine tissue, using single microarray platform-preliminary results," Clinical Transplantation, vol. 18, supplement 12, pp. 76-80, 2004.

[45] H. J. Rothkötter, "Anatomical particularities of the porcine immune system-A physician's view," Developmental and Comparative Immunology, vol. 33, no. 3, pp. 267-272, 2009.
[46] J. E. Butler, K. M. Lager, I. Splichal et al., "The piglet as a model for B cell and immune system development," Veterinary Immunology and Immunopathology, vol. 128, no. 1-3, pp. 147-170, 2009.

[47] J. E. Butler and M. Šinkora, "The isolator piglet: a model for studying the development of adaptive immunity," Immunologic Research, vol. 39, no. 1-3, pp. 33-51, 2007.

[48] L. Piriou-Guzylack and H. Salmon, "Membrane markers of the immune cells in swine: an update," Veterinary Research, vol. 39, no. 6, p. 54, 2008.

[49] A. Saalmüller, G. Kuebart, E. Hollemweguer et al., "Summary of workshop findings for porcine T-lymphocytespecific monoclonal antibodies," Veterinary Immunology and Immunopathology, vol. 80, no. 1-2, pp. 35-52, 2001.

[50] K. Haverson, A. Saalmüller, B. Alvarez et al., "Overview of the Third International Workshop on Swine Leukocyte Differentiation Antigens," Veterinary Immunology and Immunopathology, vol. 80, no. 1-2, pp. 5-23, 2001.

[51] W. J. A. Boersma, R. J. Zwart, J. Sinkora, Z. Rehakova, K. Haverson, and A. T. J. Bianchi, "Summary of workshop findings for porcine B-cell markers," Veterinary Immunology and Immunopathology, vol. 80, no. 1-2, pp. 63-78, 2001.

[52] J. K. Lunney, K. Walker, and T. Goldman, "Analyses of anti-human CD monoclonal antibodies for cross reactions with swine cell antigens," Veterinary Immunology and Immunopathology, vol. 43, no. 1-3, pp. 207-210, 1994.

[53] J. K. Lunney, K. Walker, T. Goldman et al., "Overview of the First International Workshop to Define Swine Leukocyte Cluster of Differentiation (CD) Antigens," Veterinary Immunology and Immunopathology, vol. 43, no. 1-3, pp. 193206, 1994.

[54] M. D. Pescovitz, B. K. Book, B. Aasted et al., "Summary of workshop findings for antibodies reacting with porcine T-cells and activation antigens: results from the Second International Swine CD Workshop," Veterinary Immunology and Immunopathology, vol. 60, no. 3-4, pp. 251-260, 1998.

[55] A. Saalmüller, S. Denham, K. Haverson et al., "The Second International Swine CD Workshop," Veterinary Immunology and Immunopathology, vol. 54, no. 1-4, pp. 155-158, 1996.

[56] A. Saalmüller, T. Pauly, B. Aasted et al., "Summary of the first round analyses of the Second International Swine CD Workshop," Veterinary Immunology and Immunopathology, vol. 60, no. 3-4, pp. 237-249, 1998.

[57] A. Saalmüller, T. Pauly, J. K. Lunney et al., "Overview of the Second International Workshop to define Swine Cluster of Differentiation (CD) antigens," Veterinary Immunology and Immunopathology, vol. 60, no. 3-4, pp. 207-228, 1998.

[58] P. Sopp, L. Redknap, and C. Howard, "Cross-reactivity of human leucocyte differentiation antigen monoclonal antibodies on porcine cells," Veterinary Immunology and Immunopathology, vol. 60, no. 3-4, pp. 403-408, 1998.

[59] A. I. Pearce, R. G. Richards, S. Milz, E. Schneider, and S. G. Pearce, "Animal models for implant biomaterial research in bone: a review," European Cells and Materials, vol. 13, pp. 110, 2007.

[60] T. W. Olsen, S. Sanderson, X. Feng, and W. C. Hubbard, "Porcine sclera: thickness and surface area," Investigative Ophthalmology and Visual Science, vol. 43, no. 8, pp. 25292532, 2002.

[61] M. M. Swindle, A. C. Smith, K. Laber-Laird, and L. Dungan, "Swine in biomedical research: management and models," Institute of Laboratory Journal, vol. 36, no. 1, 1994. 
[62] D. M. Schwalb, M. Eshghi, R. Evans et al., "The minipig as a practical endourologic model," Journal of Endourology, vol. 3, no. 1, pp. 85-90, 1989.

[63] A. P. Evan, L. R. Willis, B. Connors, G. Reed, J. A. McAteer, and J. E. Lingeman, "Shock wave lithotripsy-induced renal injury," American Journal of Kidney Diseases, vol. 17, no. 4, pp. 445-450, 1991.

[64] J. M. Power and A. M. Tonkin, "Large animal models of heart failure," Australian and New Zealand Journal of Medicine, vol. 29, no. 3, pp. 395-402, 1999.

[65] L. M. Panepinto and R. W. Phillips, "The Yucatan miniature pig: characterization and utilization in biomedical research," Laboratory Animal Science, vol. 36, no. 4, pp. 344-347, 1986.

[66] H. W. Ruelius, "Extrapolation from animals to man: predictions, pitfalls and perspectives," Xenobiotica, vol. 17, no. 3, pp. 255-265, 1987.

[67] E. Anzenbacherová, P. Anzenbacher, Z. Svoboda et al., "Minipig as a model for drug metabolism in man: comparison of in vitro and in vivo metabolism of propafenone," Biomedical Papers of the Medical Faculty of the University Palacký, Olomouc, Czechoslovakia., vol. 147, no. 2, pp. 155159, 2003.

[68] G. Bode, P. Clausing, F. Gervais et al., "The utility of the minipig as an animal model in regulatory toxicology," Journal of Pharmacological and Toxicological Methods, vol. 62, no. 3, pp. 196-220, 2010.

[69] P. Vodička, K. Smetana, B. Dvořánková et al., “The miniature pig as an animal model in biomedical research," Annals of the New York Academy of Sciences, vol. 1049, pp. 161-171, 2005.

[70] A. Aguilar, R. Alvarez-Vijande, S. Capdevila, J. Alcoberro, and A. Alcaraz, "Antioxidant patterns (superoxide dismutase, glutathione reductase, and glutathione peroxidase) in kidneys from non-heart-beating-donors: experimental study," Transplantation Proceedings, vol. 39, no. 1, pp. 249-252, 2007.

[71] D. R. Mendes, R. Gibanel, S. Capdevila et al., "Strategies to enhance organ viability in a non-heart-beating donor extracorporeal recirculation transplant model in pigs," Transplantation Proceedings, vol. 35, no. 2, pp. 845-846, 2003.

[72] S. A. Hosgood and M. L. Nicholson, "Hydrogen sulphide ameliorates ischaemia-reperfusion injury in an experimental model of non-heart-beating donor kidney transplantation," British Journal of Surgery, vol. 97, no. 2, pp. 202-209, 2010.

[73] S. A. Hosgood, B. Yang, A. Bagul, I. H. Mohamed, and M. L. Nicholson, "A comparison of hypothermic machine perfusion versus static cold storage in an experimental model of renal ischemia reperfusion injury," Transplantation, vol. 89, no. 7, pp. 830-837, 2010.

[74] M. L. Nicholson, S. A. Hosgood, M. S. Metcalfe, J. R. Waller, and N. R. Brook, "A comparison of renal preservation by cold storage and machine perfusion using a porcine autotransplant model," Transplantation, vol. 78, no. 3, pp. 333-337, 2004.

[75] M.-H.J. Maathuis, S. Manekeller, A. Van Der Plaats et al., "Improved kidney graft function after preservation using a novel hypothermic machine perfusion device," Annals of Surgery, vol. 246, no. 6, pp. 982-989, 2007.

[76] J. P. Richer, L. Lacoste, J. P. Faure, TH. Hauet, J. C. Ferrie, and M. Carretier, "Sacrococcygeal and transsacral epidural anesthesia in the laboratory pig: a model for experimental surgery," Surgical and Radiologic Anatomy, vol. 20, no. 6, pp. 431-435, 1998.
[77] E. Bures, J. Fusciardi, H. Lanquetot, K. Dhoste, J. P. Richer, and L. Lacoste, "Ventilatory effects of laparoscopic cholecystectomy," Acta Anaesthesiologica Scandinavica, vol. 40, no. 5, pp. 566-573, 1996.

[78] L. Lacoste, S. Bouquet, P. Ingrand, J. C. Caritez, M. Carretier, and B. Debaene, "Intranasal midazolam in piglets: pharmacodynamics ( $0.2 \mathrm{vs} 0.4 \mathrm{mg} / \mathrm{kg})$ and pharmacokinetics $(0.4 \mathrm{mg} / \mathrm{kg})$ with bioavailability determination," Laboratory Animals, vol. 34, no. 1, pp. 29-35, 2000.

[79] M. Carretier, J. P. Richer, J. Rouffineau, J. Karayan, L. Lacoste, and J. M. Pechier, "Perfecting a model of orthotopic liver/small bowel transplantation in pigs: determination of the best harvesting and transplantation technique," Transplantation Proceedings, vol. 27, no. 2, pp. 1717-1719, 1995.

[80] A. Rojas-Pena, J. L. Reoma, E. Krause et al., "Extracorporeal support: improves donor renal graft function after cardiac death," American Journal of Transplantation, vol. 10, no. 6, pp. 1365-1374, 2010.

[81] H. Buchwald, H. J. Menchaca, N. Van Michalek et al., "Microorifice metabolic/bariatric surgery under IV sedation/local anesthesia: porcine feasibility study," Obesity Surgery, vol. 20, no. 4, pp. 500-505, 2010.

[82] S. Von Delius, D. Wilhelm, H. Feussner et al., "Natural orifice transluminal endoscopic surgery: cardiopulmonary safety of transesophageal mediastinoscopy," Endoscopy, vol. 42, no. 5, pp. 405-412, 2010.

[83] R. M. de Oliveira Clark, A. B. Neto, E. H. Bianchi, and L. R. de Carvalho, "Evaluation of hemodynamic, metabolic, and electrolytic changes after graft reperfusion in a porcine model of intestinal transplantation," Transplantation Proceedings, vol. 42, no. 1, pp. 87-91, 2010.

[84] P. W. Y. Chiu, E. K. Wai Ng, A. Y. B. Teoh, C. C. H. Lam, J. Y. W. Lau, and J. J. Y. Sung, "Transgastric endoluminal gastrojejunostomy: technical development from bench to animal study (with video)," Gastrointestinal Endoscopy, vol. 71, no. 2, pp. 390-393, 2010.

[85] D. Dragun, U. Hoff, J. K. Park et al., "Ischemia-reperfusion injury in renal transplantation is independent of the immunologic background," Kidney International, vol. 58, no. 5, pp. 2166-2177, 2000.

[86] M. Golling, H. Kellner, H. Fonouni et al., "Reduced glutathione in the liver as a potential viability marker in nonheart-beating donors," Liver Transplantation, vol. 14, no. 11, pp. 1637-1647, 2008.

[87] J. Cau, F. Favreau, K. Zhang et al., "FR167653 improves renal recovery and decreases inflammation and fibrosis after renal ischemia reperfusion injury," Journal of Vascular Surgery, vol. 49, no. 3, pp. 728-740, 2009.

[88] J. Cau, F. Favreau, J. P. Tillement, L. O. Lerman, T. Hauet, and J. M. Goujon, "Trimetazidine reduces early and long-term effects of experimental renal warm ischemia: a dose effect study," Journal of Vascular Surgery, vol. 47, no. 4, pp. 852860, 2008.

[89] C. Jayle, J. P. Faure, R. Thuillier, J. M. Goujon, J. P. Richer, and T. Hauet, "Influence of nephron mass and a phosphorylated 38 mitogen-activated protein kinase inhibitor on the development of early and long-term injury after renal warm ischaemia," British Journal of Surgery, vol. 96, no. 7, pp. 799808, 2009.

[90] X. Wen, R. Murugan, Z. Peng, and J. A. Kellum, "Pathophysiology of acute kidney injury: a new perspective," Contributions to Nephrology, vol. 165, pp. 39-45, 2010. 
[91] C. Jayle, F. Favreau, K. Zhang et al., "Comparison of protective effects of trimetazidine against experimental warm ischemia of different durations: early and long-term effects in a pig kidney model," American Journal of Physiology, vol. 292, no. 3, pp. F1082-F1093, 2007.

[92] C. Doucet, S. Milin, F. Favreau et al., "A p38 mitogenactivated protein kinase inhibitor protects against renal damage in a non-heart-beating donor model," American Journal of Physiology, vol. 295, no. 1, pp. F179-F191, 2008.

[93] I. Jochmans, E. Lerut, V. Heedfeld, T. Wylin, J. Pirenne, and D. Monbaliu, "Reproducible model for kidney autotransplantation in pigs," Transplantation Proceedings, vol. 41, no. 8, pp. 3417-3421, 2009.

[94] B. Deroure, N. Kamar, H. Depreneuf et al., "Expanding the criteria of renal kidneys for transplantation: use of donors with acute renal failure," Nephrology Dialysis Transplantation, vol. 25, no. 6, pp. 1980-1986, 2010.

[95] C. Moers, H. G. D. Leuvenink, and R. J. Ploeg, "Non-heart beating organ donation: overview and future perspectives," Transplant International, vol. 20, no. 7, pp. 567-575, 2007.

[96] J. P. Faure, H. Baumert, Z. Han et al., "Evidence for a protective role of trimetazidine during cold ischemia: targeting inflammation and nephron mass," Biochemical Pharmacology, vol. 66, no. 11, pp. 2241-2250, 2003.

[97] T. Hauet, J. M. Goujon, A. Vandewalle et al., "Trimetazidine reduces renal dysfunction by limiting the cold ischemia/reperfusion injury in autotransplanted pig kidneys," Journal of the American Society of Nephrology, vol. 11, no. 1, pp. 138-148, 2000.

[98] T. Hauet, H. Baumert, H. Gibelin, C. Godart, M. Carretier, and M. Eugene, "Citrate, acetate and renal medullary osmolyte excretion in urine as predictor of renal changes after cold ischaemia and transplantation," Clinical Chemistry and Laboratory Medicine, vol. 38, no. 11, pp. 1093-1098, 2000.

[99] T. Hauet, H. Gibelin, J. P. Richer, C. Godart, M. Eugene, and M. Carretier, "Influence of retrieval conditions on renal medulla injury: evaluation by proton NMR spectroscopy in an isolated perfused pig kidney model," Journal of Surgical Research, vol. 93, no. 1, pp. 1-8, 2000.

[100] H. Baumert, J. P. Richer, H. Gibelin et al., "Early evaluation of renal medulla injury by $\mathrm{H}$ nuclear magnetic resonance spectroscopy after preservation and transplantation," Transplantation Proceedings, vol. 32, no. 2, pp. 498-499, 2000.

[101] J. P. Faure, I. Petit, K. Zhang et al., "Protective roles of polyethylene glycol and trimetazidine against cold ischemia and reperfusion injuries of pig kidney graft," American Journal of Transplantation, vol. 4, no. 4, pp. 495-504, 2004.

[102] R. Thuillier, F. Favreau, O. Celhay, L. MacChi, S. Milin, and T. Hauet, "Thrombin inhibition during kidney ischemiareperfusion reduces chronic graft inflammation and tubular atrophy," Transplantation, vol. 90, no. 6, pp. 612-621, 2010.

[103] N. Vaziri, R. Thuillier, F. Favreau et al., "Analysis of machine perfusion benefits in kidney grafts: a preclinical study," Journal of Translational Medicine, vol. 9, no. 15, 2011.

[104] S. Giraud, R. Thuillier, A. Belliard et al., "Direct thrombin inhibitor prevents delayed graft function in a porcine model of renal transplantation," Transplantation, vol. 87, no. 11, pp. 1636-1644, 2009.

[105] C. Doucet, D. Dutheil, I. Petit et al., "Influence of colloid, preservation medium and trimetazidine on renal medulla injury," Biochimica et Biophysica Acta, vol. 1673, no. 3, pp. 105-114, 2004.
[106] I. Matl, P. Hribova, E. Honsova, I. Brabcova, and O. Klicky, "Potential predictive markers in protocol biopsies for premature renal graft loss," Kidney and Blood Pressure Research, vol. 33, no. 1, pp. 7-14, 2010.

[107] J. M. Goujon, A. Vandewalle, H. Baumert, M. Carretier, and T. Hauet, "Influence of cold-storage conditions on renal function of autotransplanted large pig kidneys," Kidney International, vol. 58, no. 2, pp. 838-850, 2000.

[108] B. M. Doorschodt, M. C. Schreinemachers, M. Behbahani et al., "Hypothermic machine perfusion of kidney grafts: which pressure is preferred?" Annals of Biomedical Engineering, vol. 39, no. 3, pp. 1051-1059, 2011.

[109] S. A. Hosgood, A. D. Barlow, P. J. Yates et al., "A pilot study assessing the feasibility of a short period of normothermic preservation in an experimental model of non heart beating donor kidneys," Journal of Surgical Research. In press.

[110] G. La Manna, D. Conte, M. L. Cappuccilli et al., "An in vivo autotransplant model of renal preservation: cold storage versus machine perfusion in the prevention of ischemia/reperfusion injury," Artificial Organs, vol. 33, no. 7, pp. 565-570, 2009.

[111] J. Treckmann, M. Nagelschmidt, T. Minor, F. Saner, S. Saad, and A. Paul, "Function and quality of kidneys after cold storage, machine perfusion, or retrograde oxygen persufflation: results from a porcine autotransplantation model," Cryobiology, vol. 59, no. 1, pp. 19-23, 2009.

[112] M.-C.J.M. Schreinemachers, B. M. Doorschodt, S. Florquin et al., "Improved preservation and microcirculation with POLYSOL after transplantation in a porcine kidney autotransplantation model," Nephrology Dialysis Transplantation, vol. 24, no. 3, pp. 816-824, 2009.

[113] P. J. Garvin, M. L. Niehoff, S. M. Robinson et al., "Renoprotective effects of the 21-aminosteroid U74389G in ischemiareperfusion injury and cold storage preservation," Transplantation, vol. 63, no. 2, pp. 194-201, 1997.

[114] L. P. Perrault, M.-C. Aubin, O. Malo et al., "Status of the endothelium-derived hyperpolarizing factor pathway in coronary arteries after heterotopic heart transplantation," Journal of Heart and Lung Transplantation, vol. 26, no. 1, pp. 48-55, 2007.

[115] I. El-Hamamsy, L.-M. Stevens, P. M. Vanhoutte, and L. P. Perrault, "Injury of the coronary endothelium at implantation increases endothelial dysfunction and intimal hyperplasia after heart transplantation," Journal of Heart and Lung Transplantation, vol. 24, no. 3, pp. 251-258, 2005.

[116] L. P. Perrault, J. P. Bidouard, N. Desjardins, N. Villeneuve, J. P. Vilaine, and P. M. Vanhoutte, "Comparison of coronary endothelial dysfunction in the working and nonworking graft in porcine heterotopic heart transplantation," Transplantation, vol. 74, no. 6, pp. 764-772, 2002.

[117] R. Thuillier, S. Giraud, F. Favreau et al., "Improving longterm outcome in allograft transplantation: role of ionic composition and polyethylene glycol," Transplantation. In press.

[118] M. G. Snoeijs, R. A. Matthijsen, S. Seeldrayers et al., "Autologous Transplantation of Ischemically Injured Kidneys in Pigs," Journal of Surgical Research. In press.

[119] J. Yoshida, K. S. Ozaki, M. A. Nalesnik et al., "Ex vivo application of carbon monoxide in UW solution prevents transplant-induced renal ischemia/reperfusion injury in pigs," American Journal of Transplantation, vol. 10, no. 4, pp. 763-772, 2010. 
[120] N. R. Obeid, A. Rojas, J. L. Reoma et al., "Organ donation after cardiac determination of death (DCD): a swine model," American Society for Artificial Internal Organs Journal, vol. 55, no. 6, pp. 562-568, 2009.

[121] N. Poirier, F. Maillet, M. L. Barussaud et al., "Acute humoral rejection of renal transplants in alloimmunized pigs," Journal of Surgical Research, vol. 139, no. 2, pp. 261-268, 2007.

[122] Y. Tang, Y. P. Li, J. S. Li et al., "Impact of portal versus systemic venous drainage on acute rejection of simultaneous pancreas-kidney transplantation in pig," Transplantation, vol. 84, no. 5, pp. 629-633, 2007.

[123] A. Bagul, S. A. Hosgood, M. Kaushik, and M. L. Nicholson, "Effects of erythropoietin on ischaemia/reperfusion injury in a controlled nonheart beating donor kidney model," Transplant International, vol. 21, no. 5, pp. 495-501, 2008.

[124] M. A. Orvieto, S. R. Tolhurst, M. S. Chuang et al., "Defining maximal renal tolerance to warm ischemia in porcine laparoscopic and open surgery model," Urology, vol. 66, no. 5, pp. 1111-1115, 2005.

[125] F. Favreau, X. Y. Zhu, J. D. Krier et al., "Revascularization of swine renal artery stenosis improves renal function but not the changes in vascular structure," Kidney International, vol. 78, no. 11, pp. 1110-1118, 2010.

[126] T. Desurmont, S. Giraud, J. Cau et al., "Trophic factor and FR167653 supplementation during cold storage rescue chronic renal injury," The Journal of Urology, vol. 185, no. 3, pp. 1139-1146, 2011.

[127] F. Favreau, R. Thuillier, J. Cau et al., "Anti-thrombin therapy during warm ischemia and cold preservation prevents chronic kidney graft fibrosis in a DCD model," American Journal of Transplantation, vol. 10, no. 1, pp. 30-39, 2010.

[128] R. Thuillier, C. Renard, C. Rogel-Gaillard et al., "Effect of polyethylene glycol-based preservation solutions on graft injury in experimental kidney transplantation," The British Journal of Surgery, vol. 98, no. 3, pp. 368-378, 2011.

[129] C. Doucet, K. Zhang, T. Desurmont et al., "Influence of warm ischemia time on peripheral-type benzodiazepine receptor: a new aspect of the role of mitochondria," Nephron, vol. 107, no. 1, pp. e1-e11, 2007.

[130] C. Jayle, S. Milinkevitch, F. Favreau et al., "Protective role of selectin ligand inhibition in a large animal model of kidney ischemia-reperfusion injury," Kidney International, vol. 69, no. 10, pp. 1749-1755, 2006.

[131] B. R. Rosengard, S. Feng, E. J. Alfrey et al., "Report of the Crystal City meeting to maximize the use of organs recovered from the cadaver donor," American Journal of Transplantation, vol. 2, no. 8, pp. 701-711, 2002.

[132] S. L. Nyberg, A. J. Matas, W. K. Kremers et al., "Improved scoring system to assess adult donors for cadaver renal transplantation," American Journal of Transplantation, vol. 3, no. 6, pp. 715-721, 2003.

[133] V. Audard, M. Matignon, K. Dahan, P. Lang, and P. Grimbert, "Renal transplantation from extended criteria cadaveric donors: problems and perspectives overview," Transplant International, vol. 21, no. 1, pp. 11-17, 2008.

[134] C. Napoli, F. de Nigris, O. Pignalosa et al., "In vivo veritas: thrombosis mechanisms in animal models," Scandinavian Journal of Clinical and Laboratory Investigation, vol. 66, no. 5, pp. 407-427, 2006.

[135] J. Herrmann, L. O. Lerman, D. Mukhopadhyay, C. Napoli, and A. Lerman, "Angiogenesis in atherogenesis," Arteriosclerosis, Thrombosis, and Vascular Biology, vol. 26, no. 9, pp. 1948-1957, 2006.
[136] Y. Chen, J. Qiao, W. Tan et al., "Characterization of porcine factor VII, X and comparison with human factor VII, X," Blood Cells, Molecules, and Diseases, vol. 43, no. 1, pp. 111$118,2009$.

[137] B. Kjærgaard, S. R. Kristensen, M. Risom, and A. Larsson, "A porcine model of massive, totally occlusive, pulmonary embolism," Thrombosis Research, vol. 124, no. 2, pp. 226-229, 2009.

[138] D. R. Gross, "Thromboembolic phenomena and the use of the pig as an appropriate animal model for research on cardiovascular devices," International Journal of Artificial Organs, vol. 20, no. 4, pp. 195-203, 1997.

[139] E. Søfteland, T. Framstad, A. Nordvik et al., "Evaluation of a porcine model to study in vivo platelet activation," Thrombosis Research, vol. 118, no. 3, pp. 341-352, 2006.

[140] C. Velik-Salchner, C. Schnürer, D. Fries et al., "Normal values for thrombelastography (ROTEM) and selected coagulation parameters in porcine blood," Thrombosis Research, vol. 117, no. 5, pp. 597-602, 2006.

[141] S. Misra, J. D. Gordon, A. A. Fu et al., "The porcine remnant kidney model of chronic renal insufficiency," Journal of Surgical Research, vol. 135, no. 2, pp. 370-379, 2006.

[142] G. Brambilla and A. Cantafora, "Metabolic and cardiovascular disorders in highly inbred lines for intensive pig farming: how animal welfare evaluation could improve the basic knowledge of human obesity," Annali dell'Istituto Superiore di Sanita, vol. 40, no. 2, pp. 241-244, 2004.

[143] M. O. Larsen and B. Rolin, "Use of the Göttingen minipig as a model of diabetes, with special focus on type 1 diabetes research," Institute of Laboratory Journal, vol. 45, no. 3, pp. 303-313, 2004.

[144] Z. P. Neeb, J. M. Edwards, M. Alloosh, X. Long, E. A. Mokelke, and M. Sturek, "Metabolic syndrome and coronary artery disease in ossabaw compared with yucatan swine," Comparative Medicine, vol. 60, no. 4, pp. 300-315, 2010.

[145] C. Von Wilmowsky, P. Stockmann, P. Metzler, I. A. Harsch, K. Amann, and K. A. Schlegel, "Establishment of a streptozotocin-induced diabetic domestic pig model and a systematic evaluation of pathological changes in the hard and soft tissue over a 12-month period," Clinical Oral Implants Research, vol. 21, no. 7, pp. 709-717, 2010.

[146] T. Thim, M. K. Hagensen, L. Drouet et al., "Familial hypercholesterolaemic downsized pig with human-like coronary atherosclerosis: a model for preclinical studies," EuroIntervention, vol. 6, no. 2, pp. 261-268, 2010.

[147] L. O. Lerman, A. R. Chade, V. Sica, and C. Napoli, "Animal models of hypertension: an overview," Journal of Laboratory and Clinical Medicine, vol. 146, no. 3, pp. 160-173, 2005.

[148] Y. Liu, Z. Wang, W. Yin et al., "Severe insulin resistance and moderate glomerulosclerosis in a minipig model induced by high-fat/high-sucrose/high-cholesterol diet," Experimental Animals, vol. 56, no. 1, pp. 11-20, 2007.

[149] M. M. Swindle, A. C. Smith, and B. J. Hepburn, "Swine as models in experimental surgery," Journal of Investigative Surgery, vol. 1, no. 1, pp. 65-79, 1988.

[150] A. Barklin, A. Larsson, C. Vestergaard et al., "Insulin alters cytokine content in two pivotal organs after brain death: a porcine model," Acta Anaesthesiologica Scandinavica, vol. 52, no. 5, pp. 628-634, 2008.

[151] A. J. Hing, M. Hicks, S. R. Garlick et al., "The effects of hormone resuscitation on cardiac function and hemodynamics in a porcine brain-dead organ donor model," American Journal of Transplantation, vol. 7, no. 4, pp. 809-817, 2007. 
[152] N. Klymiuk, B. Aigner, G. Brem, and E. Wolf, "Genetic modification of pigs as organ donors for xenotransplantation," Molecular Reproduction and Development, vol. 77, no. 3, pp. 209-221, 2010.

[153] E. Cozzi, A. W. Tucker, G. A. Langford et al., "Characterization of pigs transgenic for human decay-accelerating factor," Transplantation, vol. 64, no. 10, pp. 1383-1392, 1997.

[154] L. E. Diamond, C. M. Quinn, M. J. Martin, J. Lawson, J. L. Platt, and J. S. Logan, "A human CD46 transgenic pig model system for the study of discordant xenotransplantation," Transplantation, vol. 71, no. 1, pp. 132-142, 2001.

[155] G. W. Byrne, K. R. Mccurry, M. J. Martin, S. M. Mcclellan, J. L. Platt, and J. S. Logan, "Transgenic pigs expressing human CD59 and decay-accelerating factor produce an intrinsic barrier to complement-mediated damage," Transplantation, vol. 63, no. 1, pp. 149-155, 1997.

[156] J. Hasler-Rapacz, H. Ellegren, A. K. Fridolfsson et al., "Identification of a mutation in the low density lipoprotein receptor gene associated with recessive familial hypercholesterolemia in swine," American Journal of Medical Genetics, vol. 76, no. 5, pp. 379-386, 1998.

[157] D. H. Sachs and C. Galli, "Genetic manipulation in pigs," Current Opinion in Organ Transplantation, vol. 14, no. 2, pp. 148-153, 2009.

[158] S. Le Bas-Bernardet, I. Anegon, and G. Blancho, "Progress and prospects: genetic engineering in xenotransplantation," Gene Therapy, vol. 15, no. 18, pp. 1247-1256, 2008.

[159] B. Ekser and D. K. Cooper, "Overcoming the barriers to xenotransplantation: prospects for the future," Expert Review of Clinical Immunology, vol. 6, no. 2, pp. 219-230, 2010.

[160] B. Aigner, S. Renner, B. Kessler et al., "Transgenic pigs as models for translational biomedical research," Journal of Molecular Medicine, vol. 88, no. 7, pp. 653-664, 2010.

[161] G. Blancho, "Clinical perspectives of renal transplantationPerspectives cliniques de la xenotransplantation renale," Pathologie Biologie, vol. 48, no. 4, p. 447, 2000.

[162] J. Ashton-Chess, J. C. Roussel, R. Manez et al., "Cellular participation in delayed xenograft rejection of hCD55 transgenic pig hearts by baboons," Xenotransplantation, vol. 10, no. 5, pp. 446-453, 2003.

[163] T. A. L. Brevini, S. Antonini, F. Cillo, M. Crestan, and F. Gandolfi, "Porcine embryonic stem cells: facts, challenges and hopes," Theriogenology, vol. 68, supplement 1, pp. S206S213, 2007.

[164] B. P. V. L. Telugu, T. Ezashi, and R. M. Roberts, “The promise of stem cell research in pigs and other ungulate species," Stem Cell Reviews and Reports, vol. 6, no. 1, pp. 31-41, 2010.

[165] R. M. Roberts, B. P. V. L. Telugu, and T. Ezashi, "Induced pluripotent stem cells from swine (Sus scrofa): why they may prove to be important," Cell Cycle, vol. 8, no. 19, pp. 30783081, 2009.

[166] M. N. Jameel, Q. Li, A. Mansoor et al., "Long-term functional improvement and gene expression changes after bone marrow-derived multipotent progenitor cell transplantation in myocardial infarction," American Journal of Physiology, vol. 298, no. 5, pp. H1348-H1356, 2010. 


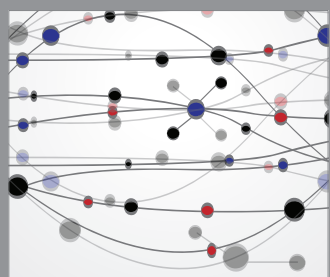

The Scientific World Journal
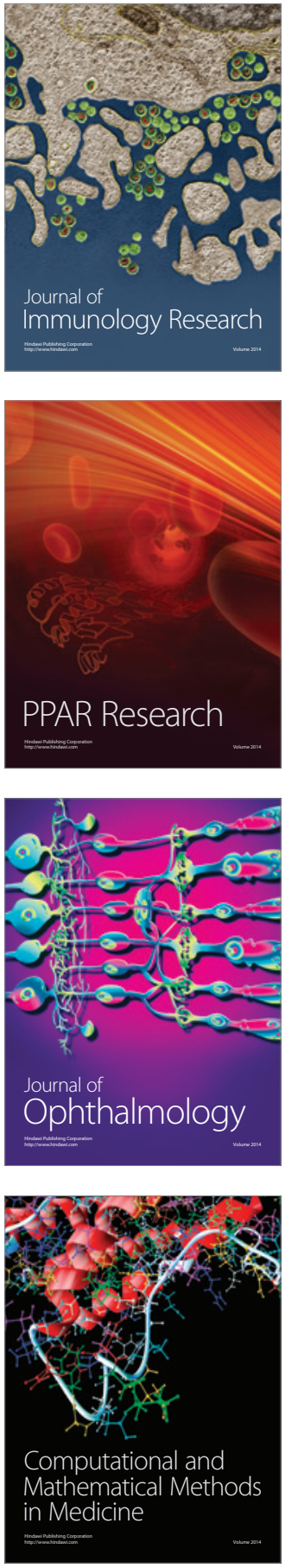

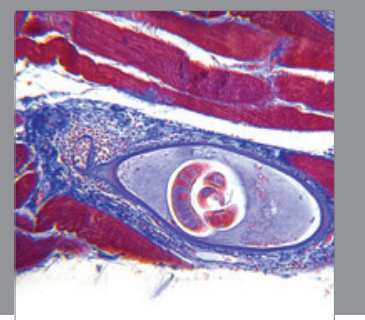

Gastroenterology

Research and Practice
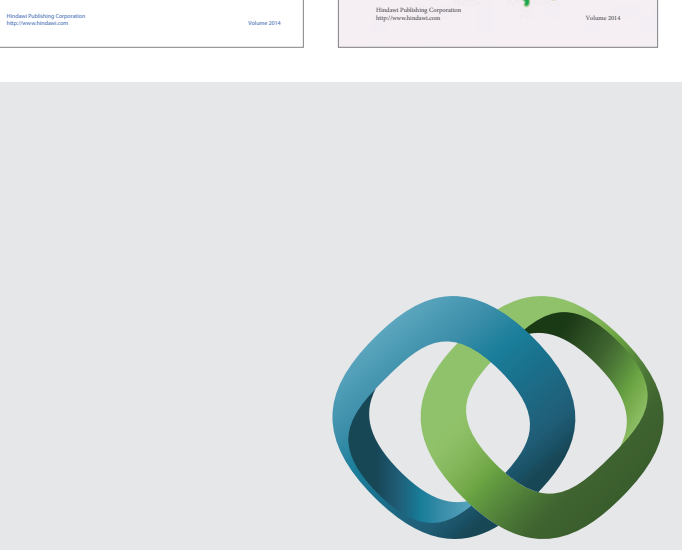

\section{Hindawi}

Submit your manuscripts at

http://www.hindawi.com
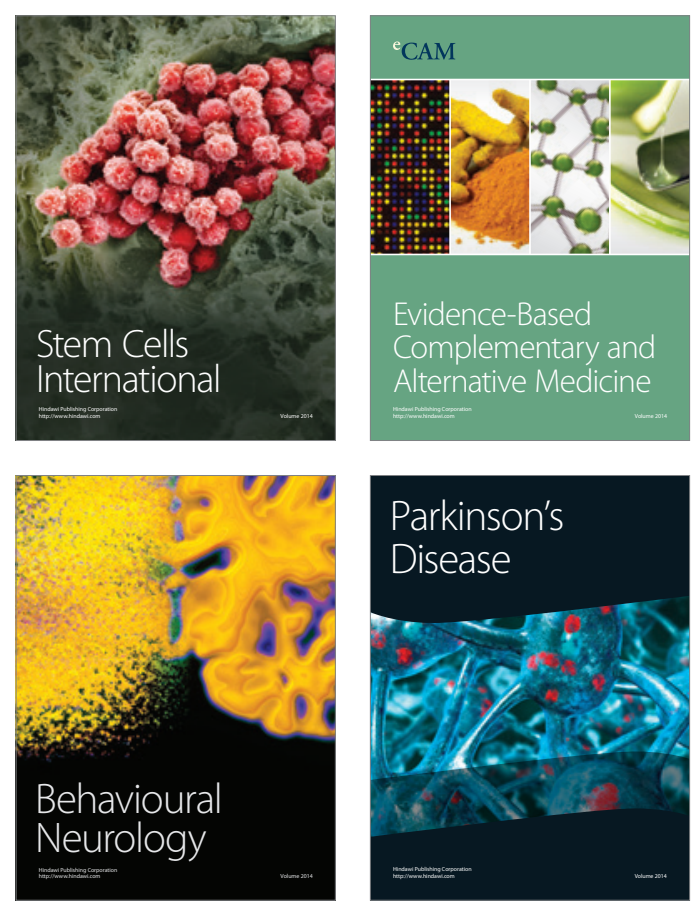

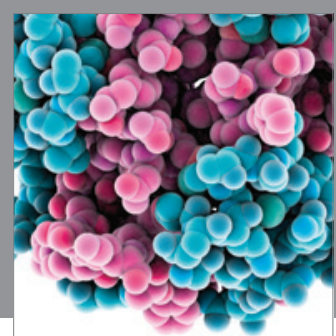

Journal of
Diabetes Research

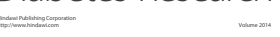

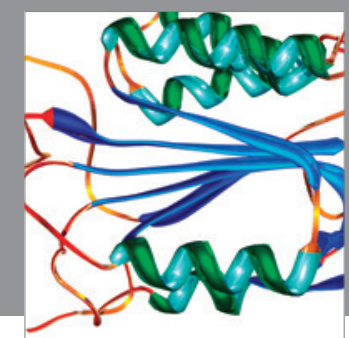

Disease Markers
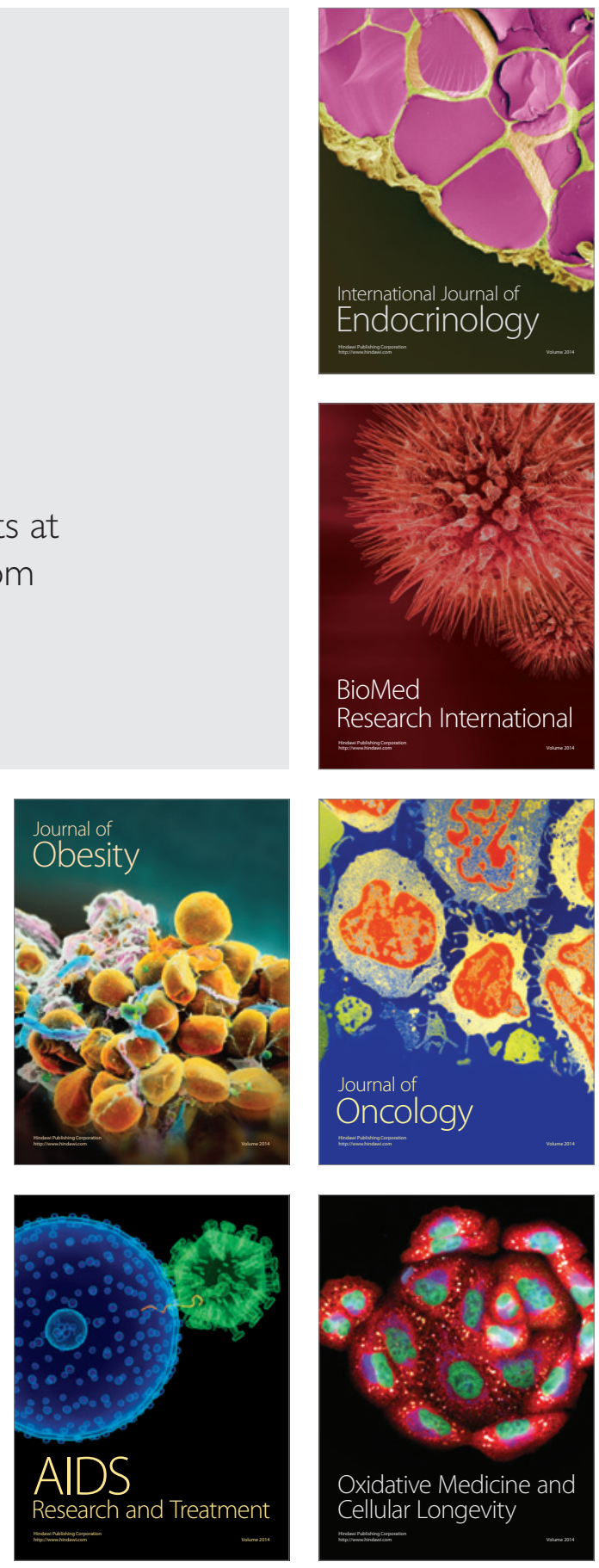